\title{
Provisional standard for tolerable level of deoxynivalenol contamination in wheat
}

\author{
Susumu KumAgAl ${ }^{* 1}$ and Toshisugu TANAKA *2 \\ *1 Department of Veterinary Public Health, University of Tokyo \\ (1-1-1 Yayoi, Bunkyo-ku, Tokyo 113-8657 Japan) \\ $* 2$ Kobe Institute of Health \\ (4-6 M inatoshima-nakamachi, Chuo-ku, Kobe 650-0046 Japan)
}

Key words: deoxynivalenol, wheat, tolerable level

(Received: October 10, 2002)

The Joint FAO/WHO Expert Committee on Food Additives (JECFA) was held on February 6-15, 2001, to evaluate toxicological data on specific mycotoxins including aflatoxin $M_{1}$, fumonisins $B 1$, $B 2$ and $B 3$, ochratoxin $A$, deoxynivalenol, and $T-2$ and HT-2 toxins. Regarding deoxynivalenol (DON), the Committee established a provisional maximum tolerable daily intake (PMTDI) as $1 \mu \mathrm{g} / \mathrm{kg}$ of body weight based on the results of a 2-year study in mice.

Since the DON contamination levels in wheat produced in Japan that had been reported in some journals prior to that time indicated a possible DON intake over the PMTDI, the Ministry of Health, Labour and Welfare organized a research group to investigate current situation of DON contamination in wheat in Japan.

To perform this research, unpolished wheat imported from three countries and that derived from two regions of Japan to analyze DON contamination. After extraction with acetonitrile-water (85: 15, v/ v) and purification with a multifunctional cleanup column, the wheat samples were analyzed by the method using LC-MS (liquid chromatography-mass spectrometry). The contamination level of DON in the imported samples (number $=20$ ) ranged from 0 (non-detectable level) to $740 \mu \mathrm{g} / \mathrm{kg}$, and those in the domestic samples ( $\mathrm{n}=36$ ) ranged from 0 to $2248 \mu \mathrm{g} / \mathrm{kg}$.
Using data of daily average intake of wheat products in Japan, and assuming $50 \%$ reduction of DON concentrations during processing of wheat, the DON levels noted in some samples were considered possibly to result in a DON intake exceeding the PMTDI proposed by JECFA.

Viewing the results of the investigation, the Joint Committee of Food Standard and Toxicity Committees under the Food Sanitation Council concluded that a standard for DON in wheat should be established to prevent adverse health effects, even though the observed contamination in unpolished wheat may not cause immediate adverse health effects. However, since much more data on DON contamination were needed to establish the standard, the Joint Committees recommended setting a provisional standard for the tolerable level of DON in wheat, and using this standard for administrative guidance, pending establishment of a standard based on further investigations. The MHLW recommended $1.1 \mathrm{mg} / \mathrm{kg}$ of DON in unpolished wheat as a provisional standard for local governments on $\mathrm{M}$ ay 21, 2002.

The analytical method recommended for testing unpolished wheat was as follows: A $50 \mathrm{~g}$ sample of finely ground unpolished wheat is extracted with 200 $\mathrm{ml}$ of acetonitrile-water (85: 15, v/ v) using an 
automatic shaker and ultrasonicator. The extract is filtered and the residue is washed with $20 \mathrm{ml}$ of extraction solvent. Acetonitrile-water ( $85: 15, \mathrm{v} / \mathrm{v}$ ) is added to the combined filtrates to $250 \mathrm{ml}$. A $10 \mathrm{ml}$ portion of the filtrate is then applied to a multifunctional cleanup column (MultiSep \#227, Romer Labs, Inc., USA) or Autoprep MF-T (Showa Denko, Japan)). After being passed through at a flow rate of $1 \mathrm{ml} / \mathrm{min}, 5 \mathrm{ml}$ of the first eluate is collected into a test tube and then evaporated to dryness at 40 ${ }^{\circ} \mathrm{C}$ under a gentle stream of nitrogen gas. For LC analysis, $1 \mathrm{ml}$ of acetonitrile-water-methanol (5:90: $5, \mathrm{v} / \mathrm{v} / \mathrm{v}$ ) is added to a test tube containing DON working standard or the purified sample and vigorously mixed with a vortex. A $20 \mu$ I portion of the test solution obtained is used for reversed phase LC analysis. DON can be separated isocratically with a $250 \times 4.6 \mathrm{~mm}$ I.D. Mightysil C 18 reversed-phase column (Kanto Chemical Co., Inc., Japan) using acetonitrile-water-methanol (5:90:5, v/ v/ v) as a mobile phase. The column temperature is $40^{\circ} \mathrm{C}$ and the flow-rate is $1 \mathrm{ml} / \mathrm{min}$. DON can be detected at $220 \mathrm{~nm}$ using a UV/ detector. GC-ECD or GC-FID can be also used instead for LC-UV. LC-MS or GC-M S should be used for further qualitative confirmation.

小麦におけるデオキシニバレノール污染レベルの暫定基準について

熊谷 進: 東京大学大学院農学生命科学研究科 (113-8657 文京区弥生 1-1-1)

田中敏嗣 : 神戶市環境保健研究所 (650-0046 神戶市中央区港島中町 4-6)

2001 年にJECFA (The Joint FAO/WHO Expert Committee on Food Additives) により，デオキシニバレ ノール(DON)の暫定一日捸取耐用量として $1 \mathrm{~kg}$ 体重当たり $1 \mu \mathrm{g}$ という值が示された . 我が国においても， 小麦污染 DON によるヒ卜健康に対するリスクが懸念されたため, 国内で流通している小麦玄麦を対象と して污染実態調査を行った . 弚の結果, 一部玄麦について, 上記の暫定一日摂取耐用量を越える摂取量を 招来することが懸念されたため, 厚生労働省はとりあえず小麦中のデオキシニバレノール污染レベルにつ いて暫定基準值（小麦玄麦 $1 \mathrm{~kg}$ 当たり $1.1 \mathrm{mg}$ ）を示し，弚れに基づいて行政指導を行うこととした。あわ せてDON の分析方法も示した .

キーワード : デオキシニバレノール, 小麦, 暫定基準值 